Tijana B. Prokopović ${ }^{1}$

Maja Z. Mladenović

Miloš R. Mihajlović ${ }^{3}$

High Business School, Niš
SCIENTIFIC REVIEW ARTICLE doi:10.5937/ekonomika1604175P

Received: November 10, 2016

Accepted: December 12, 2016

\title{
MUNICIPAL BONDS BY LOCAL GOVERNMENT
}

\begin{abstract}
Municipal bonds are used as a source of funding for local economic development and are debt securities that are issued by the city government. In recent years, interest in this type of bond in Serbia is growing, due to the low-risk investments, the realization of liquidity investors of revenue for these bonds usually are not subject to taxation, and a yield that is achieved on these bonds is generally higher than the state yield, which is achieved by investing in state bonds. Broadcast municipal bonds of the municipality is cheaper than conventional loans from banks, which is the reason of attracting a large number of investors in order to implement concrete projects.
\end{abstract}

Key words: municipal bonds, investors, income, liquidity

JEL Classification: M21, M41 i 031, 032

\section{МУНИЦИПАЛНЕ ОБВЕЗНИЦЕ ЛОКАЛНЕ САМОУПРАВЕ}

\section{Апстракт}

Муниципалне обвезнице користе се као извор финансирања локалног економског развоја и представљају дужничке ХоВ које се издају од стране градске власти. Последюих година интересовање за ову врсту обвезница у Србији расте због ниског ризика улагања, остваривања ликвидности инвеститора, прихода који код ових обвезница најчешће не подлежу опорезиваюу, а и принос који се остварује на ове обвезнице је углавном већи од приноса који се остварује улагањем у државне обвезнице. Емитовање муниципалних обвезница од стране локалне самоуправе је јефтиније од класичног задуживања код банака, што је и разлог привлачења великог броја инвеститора у цฺиљу реализащије конкретних пројеката.

Кључне речи: муниципалне обвезнице, инвеститори, приход, ликвидност

\footnotetext{
${ }^{1}$ ticapro89@gmail.com

${ }^{2}$ mmladenovic@gmail.com

${ }^{3}$ mihaajlo@yahoo.com
} 


\section{Introduction}

Bonds are debt securities that obligate the issuer to pay the investor an amount that is listed on the bond, with a particular interest on the maturity date of its billing. They can be issued by government, banks, enterprises and other financial organizations. Bonds that are issued by cities, municipalities and local authorities are called municipal bonds. When the bonds are issued by public offering, as buyers of bonds occur all domestic and foreign legal and natural persons, i.e. banks, insurance companies, pension and investment funds, as well as citizens. Before the local government announces a public call for the sale of municipal bonds, it defines with investors the purpose and use of funds that will be raised by issuing municipal bonds. It is necessary for the issuance of municipal bonds to train staff in local government. This way local government debt represents a transition from simple credit debt, to sophisticated methods of finding free capital.

\section{The term and characteristics of municipal}

Municipal bonds are debt securities issued by the city authorities, municipalities and other local communities. They are used to collect the funds necessary to cover the budget deficit, as well as for the realization of certain projects. Buyers of municipal bonds lend money to local governments, which promises them a return of principal and accrued interest at the specified time. Interest is usually paid semi-annually, while the principal may be paid at maturity and periodic. The yield on municipal bonds was achieved in most cases higher than the yield that would be achieved by investing in government bonds. In addition to achieving satisfactory interest, the investor is, in a number of cases, exempted from paying taxes.

There are three ways of selling municipal bonds in the market:

- Tender - where there are bids on a particular day by customers;

- Placement of municipal bonds through negotiations, with the use of the services of investment banks or broker-dealer company and

- $\quad$ Private placement model.

Municipal bonds are attractive for investors and because, after the business of government bonds, they carry the lowest investment risk. After the initial issue, they are most often at an appropriate list at the market on which secondary trading is carried out. Secondary trading is the instrument by which the market can show how much it values the finances of the local government. If it happens that investors no longer want to own bonds, they can sell them to investors who want to. Income from investments in municipal bonds usually are not subject to taxation and achieve relatively high wages, because the yields on these bonds usually yield higher than that achieved by investing in government bonds.

Issuance of municipal bonds of the municipality is a cheaper source of financing than a conventional bank loans. This allows reaching a large number of investors in order to implement appropriate projects. A broader investor base means and cheaper sources of financing. Issuance of municipal bonds may be made to: 
- Financing of projects that do not generate revenue;

- Financing of projects that bring income;

- Cover the deficit of the budget of local government.

In addition to covering the budget deficit, the funds may be used for:

- Building the capacity of water supply;

- Building schools;

- Construction of sports and recreational centers;

- Construction of roads and

- Regulation of the environment.

Emission of municipal bonds, according to national legislation, starts with the decision of the competent organs of local self-government on borrowing by issuing municipal bonds. After that it is necessary to have the approval of the Ministry of Finance. Otherwise, local governments can have a level of indebtedness higher than $50 \%$ of budget revenues from the previous year. If a local government approved, opens issue account with the Central Registry of Securities. Then it is necessary to Securities Commission approved the prospectus for the distribution, followed by a public invitation for subscription and payment.

Municipal bonds are divided into two groups, namely:

- General obligation bonds and

- Revenue bonds.

General obligation bonds are used for general purposes and are fully covered by collateral municipalities that they will be paid. Revenue bonds are intended for a specific project (or purpose) and are paid out of the profits of the actual project. One is because of this considered more risky than general obligation bonds.

\section{Municipal bonds or credit}

For municipal bonds it should specified when the interest is linked to them, lower than the interest on long-term loan, which the cities and municipalities have taken with a commercial bank. These bonds have a longer repayment period than is the case with the use of long-term loans, reducing the financial strain of cities and municipalities. When conducting of municipal bonds, the period of repayment of principal debt and interest is not determined by the bank, but the local government to borrow funds.

These bonds may be traded on the stock exchange, where the sale or purchase of debt can easily be transferred from one to another creditor. There is a relatively high yield on these securities and they have the security of investment, which attracts banks, investment funds and insurance companies. Payment of the budget guarantee trot and local government property.

In addition to insurance companies and pension funds, households are also engaged in buying municipal bonds, as evidenced by examples of European countries. Citizens invest in the improvement of their living standards and monitor the progress of their investments and thus achieve a secure income. More extensive use of municipal bonds is possible only when the state returns the property to local governments, when they will 
be able to guarantee asset for the issuance of bonds. The existence of a developed capital markets is a major prerequisite for trade municipal bonds.

In the case of issuing bonds, local problems should be solved individually, i.e. municipality would not have any time to wait for the decision of the Government when it is necessary: make some time to build a school or edit environment. Then he could set the problem of increasing the total debt of the country, because the government would not be able to control the level of indebtedness, various investment and construction. But broadcasting local government bonds to solve the problem of lack of funds for capital investments.

By buying bonds, the investor agrees to share the risk of economic policy with the local government. In fact, those who take part of this risk, and takes part of the award, in addition to the principal periodically realize the anticipated interest.

Emission of municipal bonds increases the efficiency of state institutions, binding them to the public represent its economic policy, which is the basis for the decision concerned the purchase or sale of bonds. So, confidence in economic policy publisher bonds is crucial for investors. A good prerequisite for this is a developed democracy and decentralization, which implies the existence of a large number of independent national and local institutions, which is a prerequisite for successful organization of public affairs financed funds generated by issuing bonds.

The issue of local government financing through classic loans or issuing bonds requires real answer because of the benefits depends on the sources of funding of projects and their implementation. Therefore it is necessary to point out the advantages and disadvantages of conventional financing loans, and issuing bonds.

Advantages of the issuance of municipal bonds:

- Cheap borrowing,

- Debt that can be traded on a regulated market; and

- Larger investor base.

Shortcomings in issuing municipal bonds:

- Relatively undeveloped instrument;

- A complex procedure of issuance; and

- The risk of failure.

The advantages in financing through loans:

- A simple procedure;

- Faster borrowing; and

- Greater certainty of success borrowing.

Deficiencies in financing through loans:

- Fails to provide the additional positive effects;

- Smaller investor base; and

- Possible changes in the business policy of the bank.

In practice, the local government decides to issue bonds only if the bids received for the issuance of bonds are more favorable than conditions for the loan. It is not difficult to determine how funding is more favorable, because the cash flows of loans and bonds largely identically structured. 
Issuance of municipal bonds consist of the following phases:

- $\quad$ Preparatory phase of the project;

- Market analysis and documentation;

- Roadshow and regulatory issues;

- Registration and payment, the listing of bonds.

\section{The preparatory phase of the project}

At this stage of the project, for its faster and more efficient implementation, it is necessary to create good conditions. First, it is necessary to obtain the opinion of the Ministry of Finance about the possibility of borrowing, without which he cannot move to the next stage. Also, it is necessary to choose the capital market advisors with experience. Otherwise, the public procurement procedure is time-demanding loans from the bond issuance process and should be (for bonds) to launch even at this stage. However, even at this preliminary stage, it is important to determine the structure of bonds (currency, period, type of voucher), although it is subject to change to a decision on their show.

\section{Market Analysis and documentation}

Identifying the credit level of demand for municipal bonds is an important activity of this phase. Local governments may, in the event that this demand is small, to terminate the process and the financing is completed by the classic loan. Otherwise, the process continues and it is necessary to choose an agent to manage and lead the process with no financial obligations to the issuer. At this stage it is necessary to collect: the tender documents for public procurement, information memorandum for obtaining bids for underwriter, as well as presentations and promotional materials required in the process of issuing municipal bonds.

\section{Roadshow and regulatory questions}

Activities carried out in this phase are: communication with potential investors, banks and non-banking financial institutions, bringing the end of the procurement activity for the loan and accepting bids for conducting underwriter of the issue. In it, the local government realizes the conditions in which they will be charged and, if it correspond to these conditions, we proceed to the next phase. It is necessary to decide on the method of debt, as well as the decision on the issuance of municipal bonds.

\section{Entrance, payments and listing of bonds at the stock market}

In this (final) stage of the local government gets the money in your account. In the case of the private placement, it is necessary with each individual investor to sign the contract on purchase of bonds, while in the case of public offer, customers filled 
entry form and pay the stated amount of the asset to the account in the bank, which is responsible for this. Upon completion of payment, with proof of funds raised, the request shall be submitted to the Securities Commission for approval on the issuance of municipal bonds. After obtaining consent, the money is available to local governments. After registration of municipal bonds in the Central Registry of Securities, the issuer may decide to include them in the regulated market.

\section{Risks for the issuance of municipal bonds}

During the issuance of municipal bonds there may occur different types of risks on which local government must take into account. Risks can be market, operational and regulatory.

\section{Market risk}

Market risk may affect the ability to raise funds on the financial markets, especially in times of crisis. The flexibility of local governments, in terms of the period of fundraising, can be the best protection against this risk. However, if the market situation is unfavorable, the ability to issue bonds on the postponement of several months would be of great importance. Since the same group of potential investors, and purchases of state and municipal bonds, it is necessary to take account of the periods when the state issues its own securities, as and when due, otherwise it can happen that you do not collect the planned funds. When you want to borrow at a fixed interest rate, it is important for local governments to monitor the relationship between variable and fixed interest rates.

\section{Operational risk}

The risk that due to ignorance of the procedure of issuing bonds users opt for borrowing through loans or issuing bonds, belongs to this category of risk. In this regard, it is important to provide good professional presentation of the whole process of local government leaders. For the successful implementation of the procedure of registration in the Central Registry of Securities require a clear structure of the bond (the amount of the coupon, maturity, currency, guarantees, options...). The best mechanism for managing this risk is the whole process of communication with regulators prior to the commencement of the formal procedure of issuing bonds. Among other things, it is necessary to take into account that the issuance of municipal bonds are not implemented at the time of the election, but that is not implemented in an election year.

\section{Regulatory risk}

Capacity utilization for local government borrowing, or reaching the upper limit of cumulative public debt of state and local government, can be a reason for giving 
a negative opinion of the Ministry of Finance of the respective local government borrowing. The only mechanism to protect against this risk the timely planning and timeliness required for the opinion of the Ministry of Finance. Legislation on this issue, as well as their application in our country is also set to slow down the whole process, after you finished the legal framework is still improving. If they are not complied with all the formal requirements for the issuance of municipal bonds, Securities Commission does not issue a permit. We believe that this risk can be reduced by using the services advisor and underwriter.

\section{Conclusion}

As mentioned, the municipal bond refers to securities issued by local governments, in order to collect funds for a settlement infrastructure, utilities and other needs of the local community. This type of bond is often called bonds free from income tax. In Serbia, the issuance of municipal bonds local government's today popular themes, and their broadcast so far was performed by Novi Sad, Sabac, Stara Pazova, Pancevo, which is an indicator of serious tendency for these projects.

Novi Sad is the first local government that has successfully organized the issuance of municipal bonds. Offer service underwriter gave 6 banks and one broker-dealer company, and wish to participate in this project expressed and pension funds, as well as several insurance companies. As for investors, and the International Finance Corporation (IFC) has expressed the desire to purchase part of the bond issue. The city of Novi Sad, by issuing municipal bonds, enlisted under much more favorable conditions than that of their projects financed through loans.

Although in our government skepticism among citizens, caused by bad events and experiences of the nineties, when they invested the funds offered high interest rates and when most of them remained without the invested principal, their responsiveness to buy bonds of Novi Sad was the height - invest in the public good, indicating the economic local patriotism.

All in all, the success of the project, about the issuance of rated bonds, it is the interest of local leaders in recognizing this phenomenon of vital importance for the development of their community. These projects, which in addition to being able to attract the owners of surplus money, also attract people from the premises: future customers, creditors, the newly created value.

\section{References}

A Gloginic., Treasury, commercial and public records, Accounting, no. 4/2000.

А, Глогинић., Благајнички, комерцијални и државни записи, Рачуноводство, бр. $4 / 2000$.

B, Cosic., B, Jorgic., And D, Pujić., (1991), The Stock Exchange of Securities and stock market business, Belgrade.

B, Draca., The banknotes on the money market, Yugoslav banking, no. 5-6 / '96. 
B. B, Prokopovic., Time for a change in consumer models, economics, Nis, no. 2/14.

D, Momirovic., M, Jankovic., And M, Randjelovic., Investment, world economy and poor countries, Economics, Nis, no. 1/16.

E, Todorovic., And B, Krstić., Investment strategies of institutional investors, Economics, Niš, no. 1-3 / 01

M, Micovic., (2003), stock exchange transactions and securities (3 Amended edt.), Faculty of Law, Kragujevac.

M, Vitez., (2000), Securities and stock exchange operations, Subotica.

N, Jovanovic., Coherence and absurdity of the Law on Securities Market related emissions, Commercial Law, no. 5-8 / 2003 Server.

R, Bozic., Perspectives of development of financial markets and investments in securities in transition economies, Economics, Nis, br.1-6 / $2000 \mathrm{~b}$.

S, Caric., (2007), Banking business and securities, Business Academy, Novi Sad.

Б, Драча., Хартије од вредности на тржишту новца, Југословенско банкарство, бр. 5-6/96.

Б, Ћосић., Б, Јоргић., и Д, Пујић., (1991), Берзе хартија од вредности и берзнаско пословање, Београд.

Б. Б, Прокоповић., Време за промену потрошачког модела, Економика, Ниш, бр. $2 / 14$

Д, Момировић., М, Јанковић., и М, Ранђеловић., Инвестиције, светска привреда и сиромашне земље, Економика, Ниш, бр. 1/16.

Е, Тодоровић., и Б, Крстић., Инвестиционе стратегије институционалних инвеститора, Економика, Ниш, бр. 1-3/01

М, Витез., (2000), Хартије од вредности и берзански послови, Суботица.

М, Мићовић., (2003), Берзански послови и хартије од вредности (3. Измењено и допуњено оздање), Правни факултет, Крагујевац.

Н, Јовановић., Смисленост и бесмисленост Закона о тржишту хартија од вредности у вези емисије, Привредно право, бр. 5-8/2003.

P, Божић., Перспективе развоја финансијског тржишта и инвестирање у хартије од вредности у транзиционим економијама, Економика, Ниш, бр.1-6/2000.

C, Царић., (2007), Банкарски послови и хартије од вредности, Привредна академија, Нови Сад. 